PRZEGLĄD BIBLIOTECZNY 2019

e-ISSN 2545-2487

\title{
DOROTA GRABOWSKA
}

Faculty of Journalism, Information and Book Studies

University of Warsaw

e-mail: d.grabowska@uw.edu.pl

ORCID: 0000-0002-2727-6942

\section{INTERNATIONAL GUIDELINES ON YOUTH LIBRARIES AND THE POLISH REALITY}

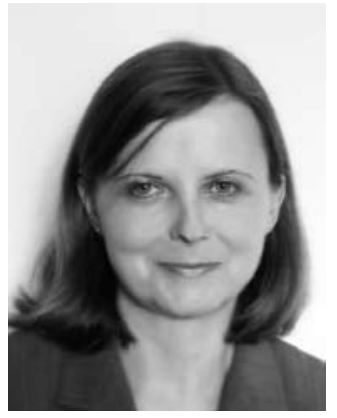

DOROTA GRABOWSKA, PhD, works at the Department for the Study of Libraries and Other Cultural Heritage Institutions at the Faculty of Journalism, Information and Book Studies of the University of Warsaw. Her research interests focus around issues related to the organization and operation of public and school libraries. She is particularly interested in the forms and methods of working with the user in the library. Since 2013, she serves as the secretary of the "Przegląd Biblioteczny" ("Library Review”). Since 2003, she has been the secretary of the "Poradnik Bibliotekarza" ("Librarian's Guide"), as well as part of the editorial team of the "Biblioteczka Poradnika Bibliotekarza" ("Librarian's Guide Library") series. She is the author of articles: „Działalność środowiskowa bibliotek w Polsce na rzecz dzieci i młodzieży” („Activity of public libraries in Poland for the benefit of children and youth"). In: Instytucje kultury jako ośrodki $\dot{z} y$ cia społecznego (Cultural institutions as centers of social life) (Warsaw: SBP Publisher, 2017, pp. 147-155); „The role of public libraries in promoting readership in Poland”. Przeglad Biblioteczny 2017, pp. 33-45; „Ujednolicanie zasad katalogowania alfabetycznego zbiorów bibliotecznych w II Rzeczypospolitej” („Unification of the alphabetical cataloguing rules for library collections in the Second Polish Republic"). In: Bibliografie specjalne. Rozwój i otwartość (Special bibliographies. Development and openness) (Warsaw: ASP OF-JR Publishing House, 2018, pp. 39-54); "Ewolucja zadań nauczycieli bibliotekarzy w dydaktyce szkolnej” ("The evolution of librarian teachers" tasks in school teaching") Studia o Ksiażce i Informacji (Studies about the book and information), 2018, No. 37, pp. 93-105.

KEYWORDS: Public libraries in Poland. Youth. Activities of public libraries. 
ABSTRACT - Objective: IFLA guidelines assume that youth libraries will function. In Polish public libraries, young people are not a group of users who are treated with special attention. This situation is not satisfactory, however, activities that may be attractive to this group of users are beginning to appear. Research methods - International guidelines, reports on youth in Poland, statistical data on public libraries and articles published last year in the "Poradnik Bibliotekarza" ("Librarian's Guide") are analysed, recognising that this is a professional journal in which librarians describe implementing "good practices". Results and Conclusions - International guidelines direct the activities of various types of libraries, including libraries for young people. Public libraries in Poland still have a lot to do in this field, although there are activities that may be attractive to this group of users. These include organising spaces for young users, using technologies, introducing activating methods, among which various types of games deserve attention, and various clubs that are being created; in addition libraries are starting to cooperate with volunteers. The situation is far from that recommended in the international guidelines, but public libraries are slowly beginning to recognize the specific needs of young people.

The International Federation of Library Associations and Institutions (IFLA), in its statutory assumptions (IFLA Statutes, p. 1), undertakes the task of setting the best standards for the development of various types of libraries. International guidelines are created that set the directions for their development. Documents on public libraries emphasize the specificity of young people as library users. The guidelines for this type of library state that: "Young people, somewhere between childhood and adulthood, are perceived as a separate social group with a specific culture characteristic for them. Public libraries must understand their needs and offer services that will meet these needs" (Działalność bibliotek, 2002, p. 43). Young people received separate guidelines, which stressed that "Young people need special attention because many of them voluntarily leave reading at this stage of life" (Guidelines for Library Services). Public libraries are designed to help transition between services for children and adults. They try to meet the needs of young people in relation to education, information, culture and leisure.

The clarification of who we consider to be young people from the perspective of libraries is not at all obvious (Grabowska, 2015, pp. 15-16). The Guidelines for libraries that support young people recognize that it is: "a set of units between childhood and adulthood" (Guidelines for Library Services). Generally, an age range of 11 to 18 years is considered. It can be extended to young people over 18 depending on the country and the cultural context. From a Polish perspective, it is difficult to agree with the lower age limit of childhood. It's easier to accept 13 years. We find such a lower limit even in the Internet International Digital Library for Children (Międzynarodowa Biblioteka cyfrowa). This age was chosen by the Bertelsmann Foundation as a starting age in projects concerning libraries for young clients (Biblioteki dla młodych, p. 5). Such libraries with the support of the Foundation were 
established in Helsinki, Los Angeles, Singapore, Dresden, and in Poland in Olsztyn and Wrocław.

Tab. 1

Structure of youth readers in public libraries in Poland in 2017

\begin{tabular}{|c|c|c|}
\hline in years & umber of readers & \% of total \\
\hline $13-15$ & 438171 & 7,3 \\
\hline $16-19$ & 484207 & 8,0 \\
\hline $20-24$ & 499340 & 8,3 \\
\hline $\mathbf{1 3 - 2 4}$ & $\mathbf{1 4 2 1 7 1 8}$ & $\mathbf{2 3 , 6}$ \\
\hline
\end{tabular}

Source: The condition of libraries in Poland covered by the Central Statistical Office survey - 2017 [online], [access: 4 June 2019]. Available in WWW: <https://www.bn.org.pl/download/document/1554115920. pdf $>$, p. 18.

In 2017, 6,020,666 readers were registered in public libraries in Poland (1.2\% less than in 2016). Youths (people between 13 and 24 years old) constituted $23.6 \%$ of the total number of people using public libraries. The trend towards a decrease among readers under 24 years old has been observed for many years, in 2017 they constituted $42.3 \%$ of readers registered in public libraries (in 2016, 44\%). Despite the decrease in the number of young people in public libraries, they still constitute an important group of users.

International guidelines assume that separate youth libraries will be operated. Given the organizational models of public libraries in Poland, libraries for children and youths dominate. Jacek Wojciechowski noted that the standards in Poland in the area of youth audiences in libraries are "disastrous", he added that "this is the biggest failure of Polish public librarianship, also highly detrimental to the future". He also claimed that "it is difficult to make any significant changes now. They would require significant costs, a different base and an organizational revolution, and one cannot see that on the side of the organisers and the librarians themselves, whoever was striving for it" (Wojciechowski, 2014, p. 224). He also stated that "a substitute solution is therefore the library offer for youths and adults together (their combination with children's agencies is a misunderstanding) - sometimes with a spatial separation of the book collection (but only the book collection) for young people. And nothing more" (Wojciechowski, 2014, p. 224). The situation of young people in public libraries has been negatively assessed, but it is worth looking at whether something is changing in this area. 
We do not have youth libraries in Poland. There have been many media libraries ("mediateka") in recent years. After Mediateka (Mediateka) in Wrocław and Planet 11 (Planeta 11) in Olsztyn, such facilities were opened, including in Kielce (2006), Warsaw (Ochota - Book Stop - 2009, Białołęka 2007, Bielany 2010), Sieradz (2009) and many other cities. Youth libraries are arranged in libraries. In the Library On Level (Biblioteka na Poziomie) (2018) of the H. Łopaciński Municipal Public Library in Lublin, literature for young people was placed on shelves next to the stairs leading to the mezzanine, with a glass floor connected to green grass and white seats. Librarians say that young readers are eager to use this space (Opałka, 2019, p. 32). Media libraries are not just libraries for young people, the change of name is to inform the public that various documents are available there, not just books. Actually, almost every public library can be considered a media library. Therefore, public libraries that support different categories of users dominate in Poland, while young people deserve special attention, as included in international guidelines, most preferably in youth libraries. In such institutions, the needs of young people should be taken into account when arranging space, gathering collections and proposing library programs. The equipment should meet the needs of young people, and the purposes of the service should be without discrimination.

Materials should be collected in accordance with the needs of young people. It is not easy because this group has very diverse interests, levels of maturity, needs, and abilities. To respond to these expectations, libraries should offer a wide variety of materials. The international guidelines assume that the offer should be broad and include: "comic books, popular literature such as science-fiction, fantasy, romances, detective stories and current popular music. Printed documents: books, magazines, newspaper clippings, brochures, folders, posters, bills, comic books, graphic novels, collections in other languages, also in Braille and sign language. Non-printed documents: audio books, music, multimedia (CD-ROM, $\mathrm{CDI})$, computer programs, video and DVD cassettes, board and computer games (electronic), access to computer networks and databases" (Guidelines for Library Services).

In 2017 in Poland, public libraries (including branches) had collections consisting of 128.4 million volumes, of which $98.5 \%$ were books, with a total of over 5 million special materials. Each public library and branch offered an average of 12 titles of current periodicals (Public Libraries in 2017). Statistics show that the non-book resources represent a small percentage of collections of public libraries. In 2017, 3618151 inventoried units of library materials were purchased for public libraries, $1 \%$ more than in the previous year, of which 3432769 volumes (0.9\% more than 2016) are books, and 15343 volumes are journals (an increase of 14.3\%). Among the other materials the biggest growth was recorded in the purchase of audiobooks 
(by $5.2 \%$ ), while fewer acquisitions were made of electronic collections on physical media (an $18.4 \%$ decrease) (State of libraries in Poland). There are more and more libraries that collect non-traditional resources, e.g. in the collection of the Beskidy Library there are over 30 historical games (Bukowska-Nowak, 2019, p. 32). The Śródmieście Library of the City Public Library in Gdynia offers non-fiction literature, including reportages, biographies, interviews and journalism, although of course, the library also offers a broad selection of fiction. In addition, e-books, audiobooks, films and board games, as well as vinyl records are available to readers (Gajewska, 2019, p. 29). On Planet 11's website, users are encouraged to come through its doors with news regarding books, films, music, audiobook, Xbox, PlayStation and PC (News). The collections should be systematically renewed, taking into account the changing interests of young people and technological changes.

In general, young people use technology efficiently (Młodzież 2016, 2016, p. 178) and use the Internet (Research Report, 2017, p. 7), so it is worthwhile that they should be able to submit documents that they are interested in via the Internet. Public libraries in Poland develop e-services (Stan bibliotek $w$ Polsce, p. 9). Its most popular form is the library website: in $2017,77.7 \%$ of library branches had one $(93.8 \%$ in cities and $69.2 \%$ in the countryside). The library website carries out many important functions: it contains information about the library, its organization, rules of use, resources and, actions taken, and serves to promote it, etc. Currently, other functionalities related to e-services are also posted on the website. The most important element is the hyperlink leading to the online catalogue, which allows searching resources and ordering library materials, with links to databases, electronic collections, and audiobooks. The website is also a starting point for other forms of communication with library users. In 2017, 15.9\% of public libraries and their branches had a form of inquiries to the librarian (or other variations, e.g. "Ask the librarian", "You have a voice", "E-wish"). They give the library the opportunity to collaborate with users, to speak on various issues regarding the functioning of libraries. With the "Ask a librarian" form, users can enter questions in a text window that most often relate to collections and the library's offer in ge-neral. "E-wish" or "Suggest a book" forms allows readers to send suggestions for buying new products, "You have a voice" allows them to comment on issues related to the functioning of the library. In 2017, at least one of the e-services indicated by the Central Statistical Office was indicated by $75.5 \%$ of library facilities (93.7\% of libraries working in cities and $65.9 \%$ in the countryside). The basic electronic service of libraries should be information on library resources - i.e. the online catalogue - available on the internet. In 2017, this service was provided by $2 / 3$ of library facilities $(66.1 \%), 89.5 \%$ of those operating in the city, $53.8 \%$ of those operating in the countryside. 
Functionalities integrated within the library system are further elements of e-services present in public libraries (eg. reader account support). E-services include activities such as the possibility of ordering library materials, booking borrowed documents, sending automatic reminders of the expiry date for their return to the user's e-mail address, as well as the possibility of remote extensions. In 2017, library facilities allowed booking of library materials $(49.1 \%)$, electronic notification of the return date $(47.2 \%)$, and extension of the return date $(41.7 \%)$. The discussed elements of remote accessibility can be an alternative for users to access the library as a place to use its resources, or obtain information about resources, including news. It is well suited to young people, who feel that they are in a hurry and do not want to waste time. A way to meet the expectations of young people may be allowing them to take part in the selection and evaluation of documents that are intended for them, as this can be a good way to promote services and collections and to increase the number of users.

International guidelines emphasize that the needs of young people should also be taken into account when planning activities. The Guidelines for Library Services propose setting up Spokespersons' Clubs whose role would be to advise on what materials might be interesting have in the libraries. In Polish libraries, young people are not treated as partners who are asked what might be attractive to them. Attempts are however being made to include them in library activities on a voluntary basis. The functioning of volunteering in Poland is regulated by Ustawa o dziatalności pożytku publicznego i wolontariacie (Act on Public Benefit Activity and Volunteerism of 24 April 2003) (Ustawa o działalności pożytku publicznego, 2003). Engaging volunteers in numerous and diverse tasks and projects can have a positive impact on the image of the library (Marciniak b, 2019, p. 8). They can perform various activities and support librarians in their works, thanks to which the library offer can be expanded, and become interesting for the local community.

The Zofia Nałkowska Municipal Public Library in Wołomin cooperates with volunteers from the "Open Heart" Youth School Parish Volunteering (Młodzieżowy Szkolno-Parafialny Wolontariat "Otwarte Serce") (Marciniak, 2019, pp. 4-8). Young people are involved in school events, such as the organization of special events or charity fundraising, but above all, they cooperate with local NGOs, foundations, and kindergartens. Youths support enterprises in the public library and in the municipal community centre, also in the commune office and, to the best of their abilities, the hospice. Although they take part in events of other institutions, they still remain volunteers of the school circle. An agreement defining the principles of participation, and mutual assistance, is drawn up with all institutions, including the library. In addition, the institution with which volunteers begin cooperation prepares a training or informational meeting, during 
which the nature of the volunteer work is explained. Youths from the "Open Heart" volunteering are very willing to take part in many projects organised by the library in Wołomin, both large and more intimate. In addition to participating in such events as World Book and Copyright Day, "Cool Librarian", "Library Night", or "National Reading", volunteers participate in various workshops for children, e.g. during the family event "Honey picking in the library" or in the Christmas meetings of "Hocus Pocus Felts". In addition, students also help librarians in their daily work, e.g. they prepare art materials needed for library lessons, organize the book collection and perform various other small library tasks. Planet 11 in Olsztyn seeks volunteers to run language cafes (Kawiarenki jezykowe), and, with the support of volunteers from the Youth Program, among others, implements many projects. However, cooperation with volunteers in public libraries is not a common occurrence (Marciniak, 2019, p. 8) and there is still a lot to be done in this area. Not to mention that they are rarely involved in advising and influencing library activities.

The international guidelines in youth work propose the implementation of such programs as: reading clubs, storytelling, and book promotion; discussion groups and clubs; thematic information meetings (on health, work, news); meetings with interesting people (authors, athletes, local personalities); performances (theater, music, art); programs for cooperation with local organizations or groups; presentations of youths' own creativity (theater, magazines, television programs, video); creative workshops, works of one's own expressivity; book debates; promotional actions for books (Guidelines for Library Services). Activation methods dominate among the recommended actions. It is a way of working during which ready knowledge is not transferred, but creates conditions for its independent absorption (Dzierzgowska, 2004, p. 9). Activation of participants is conducive to increased efficiency in acquiring knowledge, in solving problems and performing practical tasks, and also contributes to the development of young people's interests and creative attitudes (Okoń, 1998, p. 16).

All types of workshops and club activities are used for said activation. Among 1613 active Book Debating Clubs (DKK), those for youths constitute approximately $13 \% .{ }^{1}$ Different types of clubs are organized in libraries for young people. The Jan Kasprowicz City Library in Inowrocław operates the "Fantasy Station" ("Stacja Fantastyki"), formerly known as the "Club of Literature and Fantasy Film Lovers" (Klub Miłośników Li-teratury, Filmu i Fantastyki") (Kubska, 2019, pp. 31-32). A group of young people meet

\footnotetext{
${ }^{1}$ Calculated on the basis of data from the Instytut Ksiażki (Book Institute) website https://instytutksiazki.pl/kluby-ksiazki,6,gdzie-nas-znalezc, 12.html. Children's and youth clubs are not included.
} 
every Friday in the library, watch and discuss movies (adaptations of "The Lord of the Rings", "Harry Potter" and "Star Wars" were the most popular), discuss fantasy and science fiction books (they started with The Lightning's Thief by Rick Riordan). In addition, the group plays board games modelled on the works of such authors as Dmitry Glukhovsky, George R.R. Martin, H.P. Lovecraft or J.R. Tolkien, recreating the battles for the fate of Westeros when "Game of Thrones" hits the table, or struggles for the fate of Middle-earth when everyone tries to stop Sauron's army in the game "War of the Ring". Young people also reach for role-playing games during which they play different characters, perform tests and - most importantly - develop their creativity through improvisation.

In recent years, libraries more and more often use games in their work, both for educational and promotional purposes, as well as in library services (Wójcik, 2019, p. 162). They activate participants and engage them in activities as much as possible. Games in the library can be used in various areas. They can be part of collections, and libraries can also provide space for players (computer, card, board or field games). Various player clubs operate, such as the "Board Games Club" ("Klub Gier Planszowych") which operates in the Municipal Public Library in Piastów ${ }^{2}$; the same clubs also operate in the Municipal Public Library in Gliwice ${ }^{3}$, in the Public Library in the Ursus District of the Capital City Warsaw ${ }^{4}$, the Municipal Public Library in Lębork ${ }^{5}$ and many others. The Historical Games Club "Historiolandia" operates in Książnica Beskidzka (Bukowska-Nowak, 2019, pp. 31-32). The only "limitation" in this club is the theme of the board games - history. The classes are designed to convey knowledge about the history of the world through fun and healthy mental competition, from the oldest times ("Imhotep", "Augustus") to modern history ("Couriers", "Westerplatte", "Queue" etc.).

Library games are also used. In Branch 29 of the Municipal Public Library in Wrocław, during the library lesson, the game "Meanwhile in the library on Rej street" ("Tymczasem w bibliotece na Reja") is used, thanks to which users get to know the library (they learn about the library themselves, the arrangement of departments, rules of using the book collection, etc.). "By clicking on the individual icons placed on the library's photo, they must answer questions regarding e.g. the signature of the given department, or find a QR code hidden among books, after scanning which

\footnotetext{
${ }^{2}$ Klub Gier Planszowych [online], [accessed: 10.08.2019]. Available at WWW: <http:// www.piastow.naszabiblioteka.com/oferta-edukacyjna-nasze-akcje/klub-gier-planszowych>.

${ }^{3}$ Klub Gier Planszowych [online], [accessed: 10.08.2019]. Available at WWW: <https:// biblioteka.gliwice.pl/projekty/klub-gier-planszowych/>.

${ }^{4}$ Klub Gier Planszowych [online], [accessed: 10.08.2019]. Available at WWW: <http:// portal.bpursus.waw.pl/placowki/view/36>.

${ }^{5}$ Klub Gier Planszowych [online], [accessed: 10.08.2019]. Available at WWW: <http:// www.biblioteka.lebork.pl/aktualnosci-dla-dzieci/klub-gier-planszowych-2/>.
} 
they receive further tasks" (Sobieralski, 2019, p. 26). Well-designed games on the subject of libraries can contribute to the promotion of the institution, popularize knowledge about it, and build a favourable image.

Games can also be used to promote readership. First of all, those that are based on literary works, e.g. "Game of Thrones" (board game), "Harry Potter" (computer game) or "The Witcher" (computer game) serve this purpose. Sharing games based on books can be a promotion of both books and libraries themselves. Field games are also a popular way to promote books and libraries. Mobile games that have been successfully used by the Wrocław public library for several years are very popular at the Municipal Public Library there. This type of entertainment meets with great interest among current and potential - future - library readers (Sobieralski, 2019, p. 24). With the permission of the publisher or author, they use books to create mobile fun. They emphasize that the game cannot be a faithful transfer of the story told in the book, because readers who already know the content will be expecting something new. Therefore, only themes known from the novel are used, or possibly some plots. The main character in the story is usually a new character. The first such game organized by the Municipal Public Library in Wrocław in cooperation with the Znak publishing house in 2007 was "Mock - The Past Returns" ("Mock- Przeszłość powraca") (Sobieralski, 2019, p. 25). Participants helped detective Eberhard Mock solve another extremely difficult criminal puzzle. While getting acquainted with various facts from the lives of the heroes of the stories invented by librarians, examining subsequent traces and clues, answering often tricky questions, players wandered around the city to the exciting finale. Many facts woven into the game were taken from Wrocław's long, rich history. The next prepared games outside the library were: "Dziwoludy" ("Strange Creatures") based on the volume of short stories Poczet Dziwów Miejskich by Krzysztof Piskorski; "Ksenobójcy” ("Xeno-killers), referring to Orson Scott Card's Ender's Game; and "Meyer's Rule", inspired by the crime stories of Katarzyna Bondy. All games take place in an urban space.

Interesting ideas, also for young users, appear in the Libraries Development Program (Program Rozwoju Bibliotek - PRB). The project "Rozmowy przy wspólnym stole" ("Conversations at a common table") (Zapraszamy do udziatu) is open to cooperation, common reflection on important matters, and also on those that arouse controversy. It's goal is to facilitate learning about different opinions and experiences, teach conversation based on respect, trust and understanding, encourage a genuine dialogue that will have room for readiness to listen and and to give up the fight to 'win' your own opinion. “Kliknij. Sprawdź. Zrozum. Jak świadomie korzystać z informacji?" ("Click. Check. Understand. How to use information consciously?") (Kliknij. Sprawdź. Zrozum) it is a project devoted to cri- 
tical thinking, conscious use of media messages and assessment of the credibility of information. In recent years, the dissemination of false news the so-called "fake news" - has become a serious problem in the sphere of public debate. This problem reinforces negative phenomena that are also present in our country: social divisions, difficulty in conducting dialogue or reaching agreement. The project “Link do przyszłości. Zaprogramuj swoj karierę" ("Link to the future. Program your career") (Link do przyszłości) encourages young people to learn coding.

Youth in public libraries should be an important user group. The situation in Polish libraries is not satisfactory, but activities are starting to appear that may encourage young people to come to the library. However, there is still a lot to be done in this field.

\section{BIBLIOGRAPHY}

Biblioteki dla młodych klientów - scenariusz. Gütersich (b.d.). Bertelsmann Stiftung.

Biblioteki publiczne w 2017 r. [online], [accessed on: 10.08.2017]. Available on WWW: $<$ https:// www.google.com/search?client=firefox-d\&q=Biblioteki+publiczne+w+liczbach+2017> .

Bukowska-Nowak, Brygida. (2019). „Zagrać w historię” w Książnicy Beskidzkiej. Klub Gier Historycznych „Historiolandia”. Poradnik Bibliotekarza, no. 9, pp. 31-32.

Działalność bibliotek publicznych: wytyczne IFLA/UNESCO (2002). Warszawa: Wydaw. SBP.

Gajewska, Zuzanna (2019). Nowa Biblioteka Śródmieście w Gdyni. Poradnik Bibliotekarza, no. 4 , pp. 28-29.

Grabowska, Dorota (2015). Nowe technologie - młodzież - biblioteki publiczne. In: LaTeI: Z badań nad wykorzystaniem technologii informacyjnych w bibliologii i informatologii. Warszawa: Wydaw. SBP, pp. 12-25.

Guidelines for Library Services for Young Adults (Revised) [online], [accessed on: 4.06.2019]. Available on <https://www.ifla.org/publications/guidelines-for-library-services-foryoung-adults--revised-?og=8708>.

IFLA Statutes [online], [accessed on: 30.06.2019]. Available on WWW: <https://www.ifla. org/files/assets/hq/ifla-statutes-en.pdf>.

Kawiarenki językowe [online], [accessed on: 5.09.2019]. Available on WWW: <http://www. planeta11.pl/kawiarenki-jezykowe/>.

Kliknij. Sprawdź. Zrozum. Jak świadomie korzystać z informacji? [online], [accessed on: 5.09. 2019]. Available on WWW: <http://frsi.org.pl/kliknij-sprawdz-zrozum-jak-swiadomiekorzystac-z-informacji/>.

Link do przyszłości. Zaprogramuj swoją karierę [online], [accessed on: 5.09.2019]. Available on WWW: <http://linkdoprzyszlosci.pl/>.

Marciniak, Monika (2019). Wolontariat młodzieżowy w Miejskiej Bibliotece Publicznej w Wołominie. Poradnik Bibliotekarza, no. 2, pp. 4-8.

Międzynarodowa Biblioteka Cyfrowa dla Dzieci [online], [accessed on: 4.06.2019]. Available on WWW: < http://en.childrenslibrary.org/>.

Młodzież 2016 (2016). Warszawa.

Nowości [online]. [accessed on: 19.08.2019]. Available on: WWW: <http://www.planeta11. $\mathrm{pl} />$. 
Opałka, Magdalena (2019). Biblioteka na Poziomie w Lublinie. Poradnik Bibliotekarza, no. 5, pp. 31-32.

Raport z badania. Nastolatki 3.0. (2017). Warszawa.

Stan bibliotek w Polsce objętych badaniem Głównego Urzędu Statystycznego - 2017 r. [online], [accessed on: 4.06.2019]. Available on WWW: $<$ https://www.bn.org.pl/download/document/1554115920.pdf>.

Ustawa o działalności pożytku publicznego i wolontariacie z 24 kwietnia 2003 r. Dz. U. 2003 nr 96 poz. 873.

Wojciechowski, Jacek (2014). Biblioteki w nowym otoczeniu. Warszawa.

Zapraszamy do udziału w projekcie "Rozmowy przy wspólnym stole"! [online], [accessed on: 5.09.2019]. Available on: WWW: <https://biblioteki.org/aktualnosci0/Zapraszamy_do_ udzialu_w_projekcie_Rozmowy_przy_wspolnym_stole.html>. 